See discussions, stats, and author profiles for this publication at: https://www.researchgate.net/publication/330479385

\title{
Comparison of the performance of horizontal and vertical flow constructed wetland planted with Rhynchospora corymbosa
}

Article in International Journal of Phytoremediation · January 2019

DOI: $10.1080 / 15226514.2018 .1488809$

\section{CITATIONS}

5 authors, including:

Davids Olorungbon Raphael

Landmark University

14 PUBLICATIONS 8 CITATIONS

SEE PROFILE
READS

71

Kola Ogedengbe

University of Ibadan

25 PUBLICATIONS 101 CITATIONS

SEE PROFILE

Some of the authors of this publication are also working on these related projects:

Soil use patterns in Nigeria View project

wastewater quantification and characterization in a university hostel in Omuaran, Nigeria View project 


\title{
International Journal of Phytoremediation
}

\section{Comparison of the performance of horizontal and vertical flow constructed wetland planted with Rhynchospora corymbosa}

\author{
O. D. Raphael, S. I. A. Ojo, K. Ogedengbe, C. Eghobamien \& A. O. Morakinyo
}

To cite this article: O. D. Raphael, S. I. A. Ojo, K. Ogedengbe, C. Eghobamien \& A. O. Morakinyo (2019): Comparison of the performance of horizontal and vertical flow constructed wetland planted with Rhynchospora corymbosa, International Journal of Phytoremediation

To link to this article: https://doi.org/10.1080/15226514.2018.1488809

Submit your article to this journal $\widetilde{ }$

View Crossmark data $₫$ 


\title{
Comparison of the performance of horizontal and vertical flow constructed wetland planted with Rhynchospora corymbosa
}

\author{
O. D. Raphael ${ }^{a}$, S. I. A. Ojo ${ }^{b}$, K. Ogedengbe ${ }^{c}$, C. Eghobamien $^{\mathrm{b}}$, and A. O. Morakinyo ${ }^{\mathrm{b}}$
}

${ }^{\mathrm{a} D e p a r t m e n t}$ of Agricultural and Biosystems Engineering, Landmark University, Omu-Aran, Nigeria; ${ }^{\mathrm{b}}$ Department of Civil Engineering, Landmark University, Omu-Aran, Nigeria; 'Department of Agricultural and Environmental Engineering, University of Ibadan, Ibadan, Nigeria

\begin{abstract}
Treatment performance of horizontal flow (HF) and vertical flow (VF) constructed wetland planted with Rhynchospora corymbosa were compared. The average porosity of the CW beds were 0.55 , hydraulic retention time (HRT) of 3 days, hydraulic loading rate (HLR) and Organic Loading rate were $0.058 \mathrm{~m} /$ day and $3.96\left(\mathrm{~g} \cdot \mathrm{BOD} / \mathrm{m}^{2} \cdot\right.$ day), respectively with a volumetric flow rate of $0.14 \mathrm{~m}^{3} /$ day. The pollutant concentration of graywater before and after its introduction to the CWs was measured using standard sampling and analyses methods. The mean removal efficiencies (RE) for HF and VF CWs were BOD, 35\% and 35.4\%; COD, $61.9 \%$ and $56.7 \%$; TN, 87\% and 92\%; TP, 95\% and $65 \%$; TSS, $86 \%$ and $59.6 \% ; \mathbf{p H}, 8.8 \%$ and $12.8 \%$, respectively. The graywater was highly contaminated in terms of nutrient and organic load. The mean values of the parameters tested for different CWs were significantly different $(P \leq 0.05)$. This comparative study favored HF over VF Constructed wetland with HF found to be a viable alternative for graywater treatment for organics, nutrients and suspended solids removal. The result provided insight into the performance of CWs planted with R. corymbosa.
\end{abstract}

\section{KEYWORDS}

Constructed wetlands; graywater; phytoremediation; pollutant removal efficiency; Rhynchospora corymbosa

\section{Introduction}

There has been an unprecedented increase in water consumption across the globe. Consequently, studies on water reusability are gaining interest. Wastewater can be defined as spent or used water with an adversely affected quality (Shah et al. 2014). It has either dissolved or suspended contaminants in it. Reuse of treated, high-quality reclaimed wastewater for agriculture not only protects human health but also serves as a good conservation strategy by reducing the consumption of limited drinking water for irrigation and reducing fertilizer costs to the agricultural sector in low-income countries (Zurita and White 2014). Urban wastewater is usually a combination of domestic effluent which consists of blackwater (excreta, urine, and fecal sludge, i.e. toilet wastewater) and graywater (kitchen, laundry, and bathing wastewater).

Graywater is biologically polluted effluent and possesses a sanitary risk related to a potential spread of microorganisms (Matos et al. 2014). Constructed wetlands (CWs) also known as treatment wetlands are engineered systems that are developed to improve water quality with relatively low external energy requirements and easy operation and maintenance (Wu et al. 2015). These constructed wetlands combine chemical, biological, and physical treatment mechanisms in eliminating heavy metals, pathogens, organic matters, nutrients, and other pollutants that may be present in wastewater samples (Cui et al. 2010; Babatunde et al. 2011; Zhang et al. 2012). The three basic types of constructed wetland treatment systems are free water surface (FWS), horizontal subsurface flow (HF), and vertical subsurface flow (VF) wetlands. Constructed wetlands have been proven to be an effective low-cost treatment system for graywater and other wastewater types (Paulo et al. 2009; Hoffmann et al. 2011; Wurochekke et al. 2014). Constructed wetlands have been widely applied successfully in the treatment of municipal wastewater (Mburu et al. 2013), stormwater (Ávila et al. 2013), industrial wastewater ( $\mathrm{Wu}$ et al. 2015), and agricultural runoff (Yang et al. 2008). Through constructed wetland treatment, organic substances in graywater have greatly been reduced. Performance of CWs is usually based on the removal of organics, nutrients, pathogens, and emerging contaminants (Ramprasad and Philip 2016). Macrophytes are aquatic plants that grow in or near water. They can be emergent, submerged, or floating, and helophytes. They create conditions for the sedimentation of suspended solids (SS) (Srivastava et al. 2008) in association with the aquatic micro-organisms and periphytons enhance the uptake of nutrients from the water (Shelef et al. 2013). Macrophytes have been reported to transport approximately $90 \%$ of the oxygen available in the rhizosphere, which is used by microorganisms there (Vymazal 2011), utilizes nutrients in wastewater (Zhang et al. 2012) and salt phytoremediation (Shelef

CONTACT O. D. Raphael raphael.davids@Imu.edu.ng, rafdaolu2@gmail.com E Department of Agricultural and Biosystems Engineering, Landmark University, PMB 1001, Omu-Aran Kwara State, Omu-Aran, Nigeria.

Color versions of one or more of the figures in the article can be found online at www.tandfonline.com/bijp.

(C) 2019 Taylor \& Francis Group, LLC 


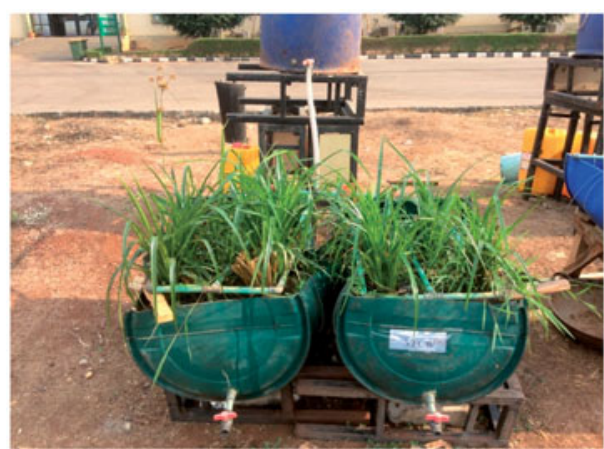

Figure 1. Picture of CW setup for VFCW and HFCW with the drain tap.

et al. 2012). This fosters the aerobic decomposition of organic matter and promotes the growth of nitrifying bacteria (Shelef et al. 2013). Phragmites australis (Common reed) is by far the most frequently used plant across the globe. Several aquatic plants such as $P$. mauritianus and Typha latifolia, water lilies (Nymphaea spontanea), Azolla papyrus (Cyperus papyrus), T. angustifola, Limnocharis flava, water hyacinth (Eichhornia crassipes), and water lettuce (Pistia stratiotes) have been used as wetlands plants to treat industrial wastewater with good results (Akinbile and Yusoff 2012). Canna indica Linn., C. alternifolius, Flabelliformis (Rottb.) Kukenth, Pennisetum purpureum, Vetiveria zizanioides, Acorus calamus Linn., Hymenocallis littoralis Jack., P. communis, and T. angustifolia Linn. Can. indica, C. flabelliformis, $P$. purpureum, and V. zizanioides are fibril root species (Canna indica possesses rhizomes, but its rhizomes have no aerenchyma and play a storage role and most of its roots are fine roots of diameter $<1 \mathrm{~mm})$. A. calamus, $H$. littoralis, $P$. communis and T. angustifolia are species with rhizomatic root. H. littoralis has no rhizome, but its root biomass is principally made of thick roots of diameter $(>1 \mathrm{~mm})$ (Chen et al. 2007). In many countries, especially in the tropics and subtropics, local plants including ornamental species are commonly used for CWs (Vymazal 2011). Although ferns like Salvinia and Azolla and large algae like Cladophora are widespread in wetlands (Akinbile et al. 2015), it is usually the flowering plants that dominate. Only a limited number of these plant species are adaptable in CWs in reality. Ewemoje and Sangodoyin (2011) evaluated the effectiveness of three macrophytes (Canna indica, P. australis and Sacciolepis africana), under varied hydraulic retention time and hydraulic loading rate in the treatment of campus sewage.

$R$. corymbosa (L.) Britton is a tropical perennial plant commonly called Golden Beak Sedge. Rhynchospora (beakrush or beak-sedge) is a genus of about 400 species of sedges with a cosmopolitan distribution (Strong 2006). A common weed of swamps often found growing in rice paddies, irrigation canals and at the edge of streams in the forest zones and southern savanna of Nigeria. It has a short root system, short rhizome without stolons and measures about $60-150 \mathrm{~cm}$ tall (Akobundu and Agyakwa 1998; Taha et al. 2015). It is frequently found in sunny habitats with wet, acidic soils. In marshes and savannas, $R$. corymbosa (L.) may be the dominant form of vegetation wherever it is found.

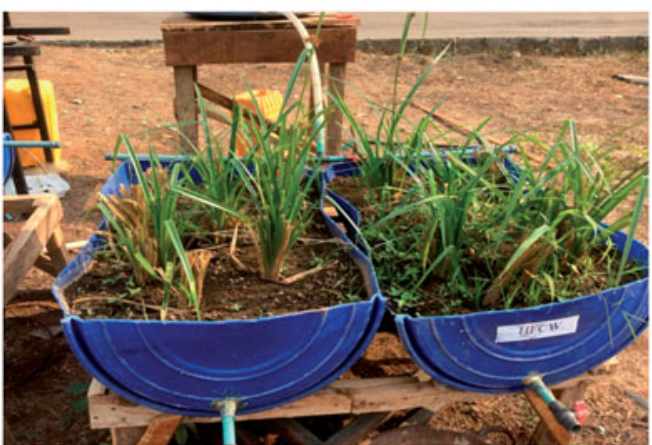

Recent studies enumerated 55 individuals in $900 \mathrm{~m}^{2}$ at three localities of mangrove communities in South-Western Nigeria (Adekanmbi et al. 2009). The inflorescences (spikelet) are sometimes subtended by bracts which can be leaflike or showy (Mani 2011). This study is to compare the performance of $\mathrm{HF}$ and VF CW systems planted with $R$. corymbosa in graywater treatment in the study area. The need for the study arises from the increased graywater generation in the study area and the need to select appropriate indigenous wetland plant for its treatment. The soil in the study area has poor infiltration property which led to the deployment of huge resources from time to time to the draining and evacuation of the septic tank facilities and disposal of wastewater into the nearby valley in the study area. Hence, there is a need for the investigation into the possibility of diversion of graywater for possible re-use and recycling. There is no known work on the phytoremediation potential of $R$. corymbosa as a constructed wetland plant.

\section{Materials and methods}

\section{The study area}

This study was carried out at the Teaching and Research Farm of Landmark University, Omu-Aran, Nigeria. It lies in the humid plain agro-ecological region of Southern Guinea Savannah of Nigeria. Omu-Aran is on latitude $8^{\circ} 8^{\prime} 00^{\prime \prime} \mathrm{N}$ and longitude $5^{\circ} 6^{\prime} 00^{\prime \prime} \mathrm{E}$ with an altitude of $564 \mathrm{~m}$ above sea level. The climate is a tropical maritime with a long rainy season and characterized by moderate weather with an annual daily average temperature range from $16-32^{\circ} \mathrm{C}$ and average annual rainfall of $1000-1150 \mathrm{~mm}$ spread over 6-8 months. Graywater used in the study was collected from the surface drain in the male and female hostel.

\section{Pilot-scale unit description}

Four different units of pilot scale CWs (two for each set) representing HFCW and VFCW were constructed. The Pilot-scale CWs were constructed from $200 \mathrm{~kg}$ polyethene oil drums. Each tank has a diameter of $600 \mathrm{~mm}$ and height of $850 \mathrm{~mm}$ with total volume of $210 \mathrm{~L}$. The drums and other fittings used were purchased from the local market. Two pilot-scale CWs were formed from a single PE drum by splitting it longitudinally into 2 halves. The capacity of each 
plastic is about $105 \mathrm{~L}$. The configuration produced two parallel systems, whose treatment capacity can be compared. The setup is shown in Figure 1. The distribution system that distinguished VFCW from other CWs was made from a $12 \mathrm{~mm}$ diameter PVC pipe with slots placed on the top of the pipes spaced at $80 \mathrm{~mm}$, to obtain an even distribution of water over the entire bed surface. This was connected to the holding tank by means of flexible hoses. The effluent in the VFCW was drained and recirculated twice in a day for the 3 days HRT period. All CW units were operated in batches with a capacity of $40 \mathrm{~L}$ per time. The selected aquatic plants $R$. corymbosa were obtained, trimmed and transplanted into the CWs in a zigzag planting pattern to regulate the flow pattern. The plant density of eight plants per square meter in each unit was observed. The plants were allowed to acclimatize in the CWs for 8 weeks before investigation commenced. The wetlands were fitted with an outlet pipe and ball valves to control the release of treated water from the wetland. The raw graywater from the hall of residence was collected and analyzed for various parameters before introducing it into the CWs. The graywater was allowed to remain within the CWs for 3 days (HRT) after which the treated water samples were collected and analyzed in the laboratory for the same sets of parameters earlier tested for.

\section{Pre-treatment system}

Pretreatment system adopted in the primary treatment of the raw graywater was slow sand filter sand (filter media size was $1-2 \mathrm{~mm}$ ) with a removable cloth bag in a holding tank placed above the sand bed in the setup. A simple cloth bag was placed above the sand filter to remove the floating and suspended matter and some amount of BOD. After each pre-treatment activity, the cloth bag was removed and cleaned before another batch of graywater was introduced into the holding tank for further treatment in the constructed wetland.

\section{Graywater sampling and analysis}

A composite sample comprising of the mixture of samples from the two halls of residence were obtained and grab samples collected in sterile bottles for analysis in the Environmental Laboratory in Landmark University. Graywater samples for nutrients analysis were collected in $2 \mathrm{~L}$ polyethene bottles rinsed with distilled water beforehand. All containers were filled to their maximum capacity so that no air was left inside and were placed in a chest box with ice to minimize any change in the parameters. Fecal coliforms, BOD5 and TSS were determined within 24 hours in the laboratory. The remaining samples were filtered and kept in the refrigerator at a temperature of $4{ }^{\circ} \mathrm{C}$. All remaining parameters were determined within 48 hours after sampling except for the BOD5.

\section{Water quality monitoring}

Water samples were collected from the effluent outlet of all CWs after the 3 day HRT period and analyzed in the laboratory. Parameter analyzed in the study were $\mathrm{pH}$, Chemical Oxygen Demand(COD), Biochemical Oxygen Demand (BOD5), Total Nitrogen (TN), Total Potassium (TK), Total Phosphorus (TP), Oil and Grease (O\&G), Total Calcium (TC), Total suspended solids (TSS), and Heavy metals ( $\mathrm{Zn}, \mathrm{Al}, \mathrm{Mg}$, and $\mathrm{Fe}$ ). All analyses were carried out according to the Standard Methods for the Examination of Water and Wastewater (APHA 2005).

\section{The substrate}

The bed depth of the substrate was $0.2 \mathrm{~m}$. It was filled as follows (from bottom to top):

- The first layer of $50 \mathrm{~mm}$ consisted of granite aggregates (size was $12-15 \mathrm{~mm}$ ) and was made to cover the inserted drain pipe fitted with a valve.

- The second layer above the first was of $150 \mathrm{~mm}$ coarse sand (filter media size was $1-2 \mathrm{~mm}$ ) into which the macrophytes was planted.

- Water surface of the average depth of $50 \mathrm{~mm}$ was allowed above the sand bed in case the system is to be adapted for a Free Water Surface CW.

- A freeboard of $50 \mathrm{~mm}$ was allowed to prevent the spilling of water from the CW tanks.

The sand media has a porosity of 55\% and Darcy's conductivity of $0.34 \mathrm{~m} / \mathrm{d}$. The flow rate was adjusted by Bucket method with the use of timer and setting of the tap. The young and new plants were acclimatized in the bed media and graywater sample was later passed through the bed. The plastic lined CWs were kept outside in the open space devoid of the shade of any form.

\section{Porosity}

The porosity of the media (soil) was experimentally determined based on the following relationship which was reported by Akratos and Tsihrintzis (2007)

$$
P(\%)=(p d-b d) \times 100
$$

where $b d=$ bulk density of the soil calculated as the ratio of dry weight of the soil sample to its volume. $p d=$ particle density calculated as the ratio of the dry weight gravel sample to the difference of volume of gravel and the volume of waste required to replace the pores.

\section{Hydraulic retention time}

The hydraulic retention time (HRT) in the wetland was calculated with Equation (2) (Crites et al. 2006):

$$
t=L W y n / Q
$$

where $t$ is the wetland HRT (day); $L$ is the length of wetland cell $(\mathrm{m}) ; W$ is the width of wetland cell $(\mathrm{m}) ; y$ is the depth of water in the wetland cell $(\mathrm{m}) ; n$ is the porosity or space available for water to flow through the wetland and $Q$ is the average flow through the wetland $\left(\mathrm{m}^{3} / \mathrm{d}\right)$. 
Table 1. Characteristics and composition of graywater in the study $(n=7){ }^{a}$

\begin{tabular}{|c|c|c|c|c|c|c|c|c|c|c|c|c|}
\hline \multirow[b]{2}{*}{ Parameters } & \multirow[b]{2}{*}{ Units } & \multicolumn{11}{|c|}{ Samples } \\
\hline & & 1 & 2 & 3 & 4 & 5 & 6 & 7 & Least & Highest & Mean & SE \\
\hline BOD & $\mathrm{mg} / \mathrm{L}$ & 72 & 68 & 66 & 60 & 57 & 62 & 54 & 54 & 72 & 63 & 6.3 \\
\hline COD & $\mathrm{mg} / \mathrm{L}$ & 1120 & 960 & 704 & 672 & 608 & 613 & 576 & 576 & 1120 & 750 & 207.5 \\
\hline TN & $\mathrm{mg} / \mathrm{L}$ & 21 & 13.8 & 14.5 & 12.9 & 15.2 & 20.5 & 17.2 & 12.9 & 21 & 16 & 3.2 \\
\hline TK & $\mathrm{mg} / \mathrm{L}$ & 4.9 & 3.2 & 3.1 & 3 & 3.2 & 8.2 & 4.1 & 3 & 8.2 & 4 & 1.9 \\
\hline TP & $\mathrm{mg} / \mathrm{L}$ & 20 & 32.2 & 89.2 & 76.2 & 96.2 & 101.2 & T. H & 20 & 101.2 & 69 & 34.6 \\
\hline O\&G & $\mathrm{mg} / \mathrm{L}$ & 1207 & 1156 & 1178 & 240.2 & 238 & 243 & 220.2 & 220.2 & 1207 & 640 & 505.4 \\
\hline $\mathrm{pH}$ & - & 7.27 & 6.84 & 8.32 & 8.03 & 8.03 & 13.05 & 7.79 & 6.84 & 13.05 & 8 & 2.1 \\
\hline TSS & $\mathrm{mg} / \mathrm{L}$ & 40 & 35 & 720 & 500 & 590 & 595 & 550 & 35 & 720 & 433 & 278.2 \\
\hline $\mathrm{Zn}$ & $\mathrm{mg} / \mathrm{L}$ & 25 & 9 & 9.6 & 7.4 & 7.4 & 12.4 & 12 & 7.4 & 25 & 12 & 6.1 \\
\hline $\mathrm{Al}$ & $\mathrm{mg} / \mathrm{L}$ & 0.32 & 0.17 & 0.19 & 0.14 & 0.14 & 5.04 & 0.23 & 0.14 & 5.04 & 1 & 1.8 \\
\hline $\mathrm{Mg}$ & $\mathrm{mg} / \mathrm{L}$ & 28 & 22 & 25 & 18 & 18 & 23 & 29 & 18 & 29 & 23 & 4.4 \\
\hline Iron & $\mathrm{mg} / \mathrm{L}$ & 6.6 & 2.55 & 2.65 & 2.05 & 2.05 & 7.05 & 3 & 2.05 & 7.05 & 4 & 2.2 \\
\hline
\end{tabular}

${ }^{a}$ Average of 6 months sampling operation, SE: standard error.

\section{Aspect ratio}

The aspect ratio selected was based on the pilot scale CW size of length $800 \mathrm{~mm}$ to the width of $300 \mathrm{~mm}$ which is 2.6: 1 (i.e. length-width ratio) is derived from Darcy's Law (Vymazal et al. 1998)

Mass Loading Rate. The following equation was used to estimate the MLR for constituents of interest for each wetland units: (Alley et al. 2013)

$$
\operatorname{MLR}=C \times Q
$$

where MLR is the mass loading rate, $\mathrm{mg} / \mathrm{day}, C$ is the concentration of the constituent of interest in the inflow water, $\mathrm{mg} / \mathrm{m}^{3}$, and $Q$ is the flow rate, $\mathrm{m}^{3} /$ day.

\section{Pollutant removal efficiency calculations}

The effect of the operational condition on wetland performance was evaluated on the basis of percent removal and mass removal rate. The percent removal (removal efficiency) was calculated as follows (Abdelhakeem et al. 2016)

$$
\text { Removal efficiency }(\%)=\frac{C_{\text {in }}-C_{\text {out }}}{C_{\text {in }}} \times 100
$$

where $C_{\text {in }}$ and $C_{\text {out }}$ is the inflow concentration and outflow concentration, respectively $(\mathrm{mg} / \mathrm{L})$. The mass removal rate $\left(r\right.$, in $\mathrm{gm}^{2} / \mathrm{d}$ ) was calculated as follows: (Abdelhakeem et al. 2016)

$$
r=q\left(C_{\text {in }}-C_{\text {out }}\right)
$$

where $r=$ mass removal rate $\left(\mathrm{gm}^{2} / \mathrm{d}\right), q=$ hydraulic loading rate $\left(\mathrm{md}^{-1}\right)$

\section{Determination of organic loading rate and hydraulic load-} ing rate

The organic loading rate, $L_{\text {org }}\left(\mathrm{g} \cdot \mathrm{BOD} / \mathrm{m}^{2}\right.$.day), was determined using the Equation (6).

$$
L_{\mathrm{org}}=\frac{C d_{\mathrm{w}} \eta}{t}
$$

Again, $C$ is the BOD $\left(\mathrm{mg} / \mathrm{L}=\mathrm{g} / \mathrm{m}^{3}\right)$ of the influent water, $d_{\mathrm{w}}(\mathrm{m})$ is the depth of the medium, which is between $0.02-0.5 \mathrm{~m}, t$ is the detention time. $\eta$ is the porosity of the medium. This number will indicate the mass of BOD per area per day that the system is expected to receive.
Hydraulic loading rate was calculated from Equation (7)

$$
\mathrm{HLR}=\frac{Q\left(\mathrm{~m}^{3} \mathrm{~d}^{-1}\right)}{S A\left(\mathrm{~m}^{2}\right)}
$$

where $Q=$ volumetric flow rate, $\mathrm{m}^{3} /$ day; $S A=$ aerial surface area, $\mathrm{m}^{2}$.

\section{Data analysis}

Microsoft Excel was used for all descriptive statistical analyses. The statistical tests were done using SPSS 22.0 software package. A significance level of $p=0.05$ was used for all statistical tests, and values reported are the mean (average) \pm standard error of the mean. When a significant difference was observed between treatments in the ANOVA procedure, it was followed by post hoc test. Multiple comparisons were made using the Least Significant Difference (LSD) test for differences between means. The null hypothesis (Ho: $\mu \mathrm{HF}=\mu \mathrm{VF}$ ) and alternate hypothesis (Ha: $\mu \mathrm{HF} \neq \mu \mathrm{VF})$ at $\alpha=0.05$ was also tested. Differences between the treatment efficiencies of HFCWs and VFCWs were also checked for different pollutants.

\section{Results and discussion}

\section{Design parameters calculation results}

The average porosity of the $\mathrm{CW}$ bed was 0.55 and calculated HRT, HLR and organic loading rate of $\mathrm{HF}$ was 3 days, $0.058 \mathrm{~m} /$ day and $3.96\left(\mathrm{~g} \cdot \mathrm{BOD} / \mathrm{m}^{2} \cdot\right.$ day $)$, respectively. All based on the highest value of pollutant recorded and volumetric flow rate of $0.014 \mathrm{~m}^{3} /$ day.

\section{Graywater quality and characterization}

The average characteristics of influent graywater fed to the wetlands are shown in Table 1. The highest value of $72 \pm 6.3 \mathrm{mg} / \mathrm{L}, 1120 \pm 207 \mathrm{mg} / \mathrm{L}, 21 \pm 3 \mathrm{mg} / \mathrm{L}, 101.2 \pm 34.6 \mathrm{mg} /$ $\mathrm{L}$ and $20-101 \pm 34.6 \mathrm{mg} / \mathrm{L}$ were the pre-treatment analyzed values obtained for BOD, COD, TN, TK, and TP, respectively. Washing detergents are the primary source of phosphates found in graywater in countries that have not yet banned phosphorus-containing detergents (Braga and 
Table 2. Percentage pollutant removal efficiency for all samples in HFCW.

\begin{tabular}{|c|c|c|c|c|c|c|c|c|c|c|c|}
\hline \multirow{2}{*}{ Parameters } & \multirow{2}{*}{ Units } & \multicolumn{6}{|c|}{ Samples (\% RE) } & \multirow{2}{*}{ Least (\% RE) } & \multirow{2}{*}{ Highest (\% RE) } & \multirow{2}{*}{ Mean } & \multirow{2}{*}{ SE } \\
\hline & & 1 & 2 & 3 & 4 & 5 & 6 & & & & \\
\hline BOD & $\mathrm{mg} / \mathrm{L}$ & 16.7 & 16.7 & 31.8 & 35 & 26.3 & 22.6 & 16.7 & 35 & 25 & 7.3 \\
\hline COD & $\mathrm{mg} / \mathrm{L}$ & 28.6 & 28.6 & 59.1 & 61.9 & 52.6 & 47.8 & 28.6 & 61.9 & 46 & 13.2 \\
\hline TN & $\mathrm{mg} / \mathrm{L}$ & 86.7 & 86.7 & 78.6 & 74.4 & 77 & 81 & 74.4 & 86.7 & 81 & 4.7 \\
\hline TK & $\mathrm{mg} / \mathrm{L}$ & 57.1 & 57.1 & 35.5 & 53.3 & 34.4 & 75.6 & 34.4 & 75.6 & 52 & 17.1 \\
\hline TP & $\mathrm{mg} / \mathrm{L}$ & 3 & 3 & 78.8 & 83.7 & 78.3 & 95.3 & 3 & 95.3 & 57 & 33.6 \\
\hline O\&G & $\mathrm{mg} / \mathrm{L}$ & 26.8 & 26.8 & 46.6 & 11.1 & 7.1 & 12 & 7.1 & 46.6 & 22 & 16.3 \\
\hline $\mathrm{pH}$ & & 3.8 & 3.8 & 2.6 & 12.7 & 10.5 & 4.5 & 2.6 & 12.7 & 6.3 & 17.3 \\
\hline TSS & $\mathrm{mg} / \mathrm{L}$ & 47.5 & 47.5 & 84.7 & 86 & 84.7 & 74.8 & 47.5 & 86 & 71 & 16.3 \\
\hline $\mathrm{Zn}$ & $\mathrm{mg} / \mathrm{L}$ & 88 & 88 & 85.4 & 91.9 & 70.3 & 87.1 & 70.3 & 91.9 & 85 & 8.3 \\
\hline $\mathrm{Al}$ & $\mathrm{mg} / \mathrm{L}$ & 65.6 & 65.6 & 94.7 & 0 & 100 & 99.6 & 0 & 100 & 71 & 42.7 \\
\hline $\mathrm{Mg}$ & $\mathrm{mg} / \mathrm{L}$ & 64.3 & 64.3 & 92 & 0 & 94.4 & 95.7 & 0 & 95.7 & 68 & 40.8 \\
\hline Iron & $\mathrm{mg} / \mathrm{L}$ & 83.3 & 83.3 & 73.6 & 82.9 & 61 & 88.7 & 61 & 88.7 & 79 & 10.9 \\
\hline
\end{tabular}

RE: removal efficiency; SE: standard error.

Table 3. Mean removal efficiencies (\%) for all CWs summary.

\begin{tabular}{|c|c|c|c|c|c|c|c|c|c|c|c|c|}
\hline \multirow{2}{*}{ CW systems } & \multirow{2}{*}{$\mathrm{pH}$} & \multicolumn{11}{|c|}{ Parameters (mg/L) } \\
\hline & & TSS & BOD & COD & TN & TP & O\&G & $\mathrm{TC}$ & ZN & $\mathrm{AL}$ & $\mathrm{Mg}$ & $\mathrm{Fe}$ \\
\hline HF effluent (\%) & 8.8 & 86 & 35 & 62 & 87 & 95 & 47 & 0 & 92 & 100 & 96 & 89 \\
\hline VF effluent (\%) & 12.8 & 59.5 & 35.4 & 56.7 & 92 & 65 & 22.6 & 0 & 91 & 32.3 & 82.5 & 93.8 \\
\hline
\end{tabular}

Varesche 2014). Hence the elevated value of TP was measured.

The values obtained for $O \& G$ was in the range $220.2-1207 \pm 505.4 \mathrm{mg} / \mathrm{L}$. The value was high even though students were not allowed to cook in the hall of residence, the unexpected high value was due to the fact that most of the body care products are oil based and wastewater from the washing of cutleries contains a high percentage of oil and these are washed down the drain. The highest value of TSS obtained was $720 \mathrm{mg} / \mathrm{L}$. For the heavy metals of $\mathrm{Al}, \mathrm{Mg}$, $\mathrm{Zn}$, and $\mathrm{Fe}$ their values were $0.14-5.04 \pm 1.8,18-29 \pm 4.4$, $7.4-25 \pm 6.1$ and $2.05-7.07 \pm 2.2 \mathrm{mg} / \mathrm{L}$, respectively. The heavy metal content of the graywater was relatively low especially the Al. One reason for the elevated values of some of the metals in the graywater could be some chlorine tablets that had been used for disinfection of water in the metallic storage tanks and plumbing fittings. These disinfectant tablets are acidic and that may cause leaching of zinc from the plumbing (Eriksson et al. 2002; Eriksson and Donner 2009). The pH ranged from $6.84-13.05 \pm 2.1$ in an alkaline direction. The characteristic of graywater was found similar to the results in different parts of Africa (Wurochekke, et al. 2014; Katukiza et al. 2015).

\section{Organic matter removal (COD, BOD, TSS) in HFCW and VFCW}

The outlet concentration of COD and TSS varied significantly in terms of pollutant removal efficiency (RE) which was as high as $61.9 \%$ and $86 \%$, respectively in HFCW. The mean value of COD RE of $46 \%$ was recorded while the average value of TSS was $71 \%$. As for the BOD, the highest value of $35 \%$ was recorded for the RE. The low BOD RE can be attributed to the low biodegradability of the graywater from the study site. The results of the analysis of the pollutant removal (PR) for samples treated in the HFCW are as shown in Table 2. The result was different from the general view that $\mathrm{HF}$ supports high organic removal as in Tuszyńska and Obarska-Pempkowiak (2008) in which removal of organic matter and suspended solids in a HFCW treating domestic sewage varies from $72 \%$ to $95 \%$ for SS, $71.2 \%$ to $94.1 \%$ for $\mathrm{BOD}_{5}$ and from $59.7 \%$ to $89 \%$ for COD. For this system, low BOD RE can be related to the root system of the plant $R$. corymbosa. The root system is in general, perennials with short, hardened, knotty, sometimes horizontally creeping rhizomes without stolons (Taha et al. 2015). A massive network of roots and rhizomes maintain a high biological activity in the constructed wetland, due to their ability to transport oxygen from the leaves to the roots is essential (Hoffmann et al. 2011). The wide rooting zone and vast biofilm surface area of $P$. australis as reported in Baskar et al. (2014), resulted in its higher BOD removal. For HF CWs a uniform distribution of roots in the entire filter bed is important, Vymazal (2011) reported that root-derived aerobic dynamics is very limited in HFCWs and its role is minor in periodically loaded VFCWs with short hydraulicretention times. Since microorganisms are considered key drivers in the treatment process, any factor that changes their composition, biodegradation efficiency or concentrations has a significant impact on the whole $\mathrm{CW}$ treatment efficiency (Shelef et al. 2013).

The performance of the VFCW in treating graywater influent (summary) is shown in Table 3. The mean RE for BOD, COD, and TSS in the VFCW were found to be $35.4 \%$, $56.7 \%$, and $59.5 \%$, respectively. These values were better or higher than what was observed for the Organic matter indicators in the HFCW but still relatively lower compared to what has been reported in Wurochekke et al. (2014) but agrees with the Paulo et al. (2009). The low BOD RE agrees with what was observed in Haghshenas-Adarmanabadi et al. (2016).

The average COD removal in Paulo et al. (2009) was about $48 \%$ while removal of turbidity and TSS were $81 \%$ and $84 \%$, respectively. The retention of influent in the bed 
for biological treatment was interfered with due to the intermittent reintroduction of influent to the system thereby leading to poor BOD removal and TSS.

\section{Nutrient removal ( $N$ and $P$ ) in HFCW and VFCW}

The results from the HFCW experiment show that the nutrient constituent of the graywater was highly removed. The average TN, TK, and TP were $81 \%, 52 \%$, and $57 \%$. However, the percent P.R of Nitrogen was exceptionally high. This is as a result of the shallow depth of the substrate in the pilot scale HFCW or other reasons which enhance the presence of oxygen in the system i.e. aeration. Plant growth leads to removal of nutrients such as nitrogen and phosphorus, as the oxygen transport into HFCWs is limited, enhanced nitrification cannot be expected. However, denitrification can be very efficient, (Hoffmann et al. 2011). Phosphorus removal can be achieved in CWs by adsorption and precipitation, and a small amount is also taken up by plant growth. It has been proven that HFCW can effectively remove $50-60 \%$ of nitrogen removal due to the limited oxygen transfer inside the wetland bed (Kantawanichkul and Wannasri 2013). The RE for TN and TP in the studied VFCW was $92 \%$ to $65 \%$, respectively. Plant growth leads to removal of nutrients such as nitrogen and phosphorus (Hoffmann et al. 2011). In VFCWs with sufficient oxygen supply, ammonia can be oxidized by autotrophic bacteria to nitrate; this process is called nitrification. An almost complete nitrification with $90 \%$ ammonia oxidation is commonly reported for VFCWs. It the studied systems the retention period of 3 days and twice-a-day reintroduction must have contributed to high TN removal. Studies indicated that nutrient removal was better at a higher temperature (Prochaska et al. 2007). Phosphorus removal can be achieved in CWs by adsorption and precipitation, which most times depends on the type of substrate used only small amount is also taken up by plant growth (Hoffmann et al. 2011) hence the low RE for TP.

\section{Heavy metal removal in HFCW and VFCW}

The average RE for the heavy metals in the graywater was found to be high for $\mathrm{Zn}, \mathrm{Al}, \mathrm{Mg}$, and Fe with the values of $81 \%, 71 \%, 68 \%$, and $79 \%$, respectively. Heavy metal loads from bathroom graywater are small in comparison with typical municipal wastewater loads but still do not always meet environmental quality standards for surface waters (Eriksson and Donner 2009). Heavy metals removal has been reported at $42 \%$ for manganese, $75-99 \%$ for cadmium, $26 \%$ for lead, $75.9 \%$ for silver and $66.7 \%$ for zinc. These are removed by adsorption and absorption into the filtration matrix and the leaves, shoots and rhizomes of the wetland plants (Odinga et al. 2013). This indicates that $R$. corymbosa (Cyperaceae) plants with rhizomatic roots thicker and fewer roots has an affinity for heavy metal absorption. The treatment system recorded a high RE for all heavy metals monitored. For $\mathrm{Zn}$ - 91\%, $\mathrm{Al}-32.3 \%, \mathrm{Mg}-82.5 \%$, and $\mathrm{Fe}-93.8 \%$. $\mathrm{Al}$ is the heavy metal with least concentration in all the influent

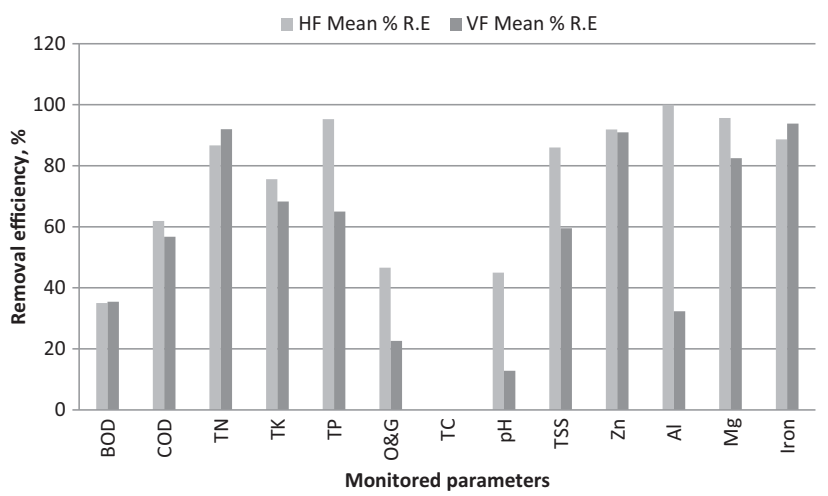

Figure 2. Graphical comparison of removal efficiencies of CWs.

sampled. There is a number of wetland processes that remove heavy metals; namely, binding to soils, sedimentation and particulate matter, precipitation as insoluble salts, and uptake by bacteria, algae, and plants (Kadlec and Knight 1996). The high RE for all heavy metals confirms the fact that $R$. corymbosa (Cyperaceae) plants roots have an affinity for heavy metal absorption.

\section{Comparison of the removal efficiencies of the CWs}

The statistical analysis shows HFCW did well in the removal of TP, O\&G, pH, $\mathrm{Al}$ and $\mathrm{Mg}$. VFCW was good for TN and Fe removal only but always ranking next to HF in performance. If all the heavy metals monitored in the study are considered to be no issue because of their detectable amount in graywater, HF will be better selected in handling other pollutants. The ANOVA analysis shows that the null hypothesis that the means of RE for the two (2) systems are equal (Ho: $\mu \mathrm{HF}=\mu \mathrm{VF})$ should be rejected and alternate hypothesis is accepted (Ha: $\mu \mathrm{HF} \neq \mu \mathrm{VF}$ ) at $\alpha=0.05$. That is the two mean values were significantly different. The decision on which of the two systems to select for graywater treatment will be based on inflow concentration, operation and maintenance, cost of construction and ancillary works, treatment goals and environmental impact of the systems. Generally, graywater does not usually contain an elevated concentration of recalcitrant pollutants as most pollutants are easily treatable.

Comparative studies have always favored HF over VF (Konnerup et al. 2011; Zhang et al. 2014). HF perform better in environmental impact (odor, Mosquito control and aesthetically appealing) low operation and maintenance cost (most times passive), low cost due to non-requirement of ancillary works like distribution pipes and intermittent reloading system (pump) and sometimes because of the agricultural reuse purpose of the effluent inefficient nutrient removal is always a non-issue. Figure 2 shows the graphical comparison of removal efficiencies of CWs. It can be deduced that for most parameters compared HFCW has better RE compared with VFCW.

\section{Conclusion}

Constructed wetlands with HF or VF are a viable alternative for graywater treatment for organics, nutrients and 
suspended solids removal. The mean removal efficiencies (RE) for $\mathrm{HF}$ and VF CWs were BOD, 35\% and 35.4\%; COD, $61.9 \%$ and $56.7 \%$; TN, $87 \%$ and $92 \%$; TP, $95 \%$ and $65 \%$; TSS, $86 \%$ and $59.6 \%$; $\mathrm{pH}, 8.8 \%$ and $12.8 \%$, respectively. Heavy metal (RE) was between $89-100 \%$ and $32-93.8 \%$ for HF and VF CWs, respectively. The odor and vector control offered by the HF concept make it attractive. The HRT $\geq$ 3 days is good for efficient pollutant removal in all CW studied. Plants are an important component of wetland systems. $R$. corymbosa as a macrophyte does not have aerial plant tissues, roots vast enough to provide surface area for microbial growth and oxygen exchange compare to other popularly used emergent macrophytes like $P$. australis, Can. indica, T. latiforal etc. The treated effluent did not meet the FEPA Nigeria standard (FEPA 1991) but the result provided insight into the performance of CWs planted with $R$. corymbosa. It is necessary to combine different systems in a hybrid form to treat graywater efficiently. The results show that (HF-VF) hybrid system will combine the good parts of the two CWs into an integrated system.

\section{Acknowledgments}

We thank the management of Landmark University for the provision of adequate laboratory equipment and the commitment of the laboratory staff and assistants. We gratefully acknowledge the critical comments and corrections of respected reviewers whose comments and corrections improved this work considerably.

\section{Disclosure statement}

The authors declared that there is no any conflict of interests.

\section{References}

Abdelhakeem SG, Aboulroos SA, Kamel MM. 2016. Performance of a vertical subsurface flow constructed wetland under different operational conditions. J Adv Res. 7(5):803-814. doi:10.1016/ j.jare.2015.12.002

Adekanmbi OH, Ogundipe OT, Olowokudejo JD. 2009. Floral diversity of South-Western Nigeria coast environments. J Sci Res Dev. 11:9-20.

Akinbile CO, Yusoff MS. 2012. Assessing water hyacinth (Eichhornia crassopes) and lettuce effectiveness in aquaculture wastewater treatment. Int J Phytoremediation. 14(3):201-211.

Akinbile CO, Ogunrinde TA, Che Bt Man H, Aziz HA. 2015. Phytoremediation of domestic wastewaters in free water surface constructed wetlands using Azolla pinnata. Int J Phytoremediation. 18(1):54-61.

Akobundu IO, Agyakwa CW. 1998. A handbook of West African Weeds. Ibadan, Nigeria: International Institute of Tropical Agriculture. $42 \mathrm{p}$.

Akratos CS, Tsihrintzis VA. 2007. Effect of temperature, HRT vegetation and porous media on removal efficiency of pilot-scale horizontal subsurface flow constructed wetlands. Ecol Eng. 29(2):173-191.

Alley BL, Willis B, Rodgers J, Castle JW. 2013. Water depths and treatment performance of pilot-scale free water surface constructed wetland treatment systems for simulated fresh oilfield produced water. Ecol Eng. 61:190-199. doi:10.1016/j.ecoleng.2013.09.021

APHA. 2005. Standard methods for the examination of water and waste water. 21st ed. Washington, DC: American Public Health Association. p. 10-15
Avila C, Garfi M, Garcia J. 2013. Three-stage hybrid constructed wetland system for wastewater treatment and reuse in warm climate regions. Ecol Eng. 6143. 9.

Braga JK, Varesche MBA. 2014. Commercial laundry water characterisation. Biochem Physiol. 01(01):8.

Babatunde AO, Zhao YQ, Doyle RJ, Rackard SM, Kumar JLG, Hu YS, 2011. Performance evaluation and prediction for a pilot two-stage on-site constructed wetland system employing dewatered alum sludge as main substrate. Bioresour Technol. 102(10):5645-5652.

Baskar G, Deeptha VT, Annadurai R. 2014. Comparison of treatment performance between constructed wetlands with different plants. IJRET. 03(04):210-214.

Chen W, Chen Z, He Q, Wang X, Wang C, Chen D, Lai Z. 2007. Root growth of wetland plants with different root types. Acta Ecologica Sinica. 27(2):450-457.

Crites RW, Middlebrooks EJ, Reed SC. 2006. Natural wastewater treatment systems. Boca Raton (FL): CRC Press.

Cui L, Ouyang Y, Lou Q, Yang F, Chen Y, Zhu W, Luo S. 2010. Removal of nutrients from wastewater with Canna indica L. under different vertical-flow constructed wetland conditions. Ecol Eng. 36(8):1083-1088.

Eriksson E, Auffarth K, Henze M, Ledin A. 2002. Characteristics of grey wastewater. Urban Water. 4(1):85. 104. [CrossRef][doi:10.1016/ S1462-0758(01)00064-4].

Eriksson E, Donner E. 2009. Metals in greywater: sources, presence and removal efficiencies, desalination. Desalination. 248(1-3):271-278.

Ewemoje O, Sangodoyin A. 2011. Developing a pilot scale horizontal sub-surface flow constructed wetlands for phytoremediation of primary lagoon effluents. Daniel Thevenot. 11th edition of the World Wide Workshop for Young Environmental Scientists(WWW-YES2011) - Urban Waters: resource or risks? Jun 2011, Arcueil, France. WWW-YES-2011 (13), 2011, WWW-YES. <hal-00607955>

FEPA. 1991. Effluent limitation guidelines for discharge of pollutants in bodies of water in Nigeria. Nigeria: Federal Environmental Protection Agency.

Haghshenas-Adarmanabadi A, Heidarpour M, Tarkesh-Esfahani S. 2016. Evaluation of horizontal-vertical subsurface hybrid constructedwetlands for tertiary treatment of conventional treatment facilities effluents in developing countries. Water Air Soil Pollut. 227(1):28. doi:10.1007/s11270-015-2718-6

Hoffmann H, Platzer, C, Winker, M, von Münch, E. 2011. Technology Review of Constructed Wetlands. Subsurface Flow Constructed Wetlands for Greywater and Domestic Wastewater Treatment. Eschborn: Deutsche Gesellschaft Fuer Internationale Zusammenarbeit (GIZ) GmbH [accessed 2017 Feb 01]. http://link. springer.com/article/10.1007/s11356-013-1533-0

Kadlec RH, Knight RL. 1996. Treatment Wetlands. Boca Raton (FL): CRC Press.

Kantawanichkul S, Wannasri S. 2013. Wastewater treatment performances of horizontal and vertical subsurface flow constructed wetland systems in tropical climate. J Sci Technol. 35(5):599-603.

Katukiza AY, Ronteltap M, Niwagaba CB, Kansiime F, Lens PN. 2015. Greywater characterization and pollutant loads in an urban slum. Int J Environ Sci Technol. 12(2):423-436.

Konnerup D, Trang NTD, Brix H. 2011. Treatment of fishpond water by recirculating horizontal and vertical flow constructed wetlands in the tropics. Aquaculture. 313(1-4):57.

Mani S. 2011. Rhynchospora corymbosa. The IUCN Red List of Threatened Species 2011: e.T177041A7364888 (accessed 2017 Apr 17). doi:10.2305/IUCN.UK.2011-1.RLTS.T177041A7364888.en.

Matos C, Pereira S, Amorim EV, Bentes I, Briga-Sa A. 2014. Wastewater and greywater reuse on irrigation in centralized and decentralized systems-an integrated approach to water quality, energy consumption and $\mathrm{CO}_{2}$ emissions. Sci Total Environ. 493:463-471.

Mburu N, Tebitendwa SM, Van Bruggen JJ, Rousseau DP, Lens PN. 2013. Performance comparison and economics analysis of waste stabilization ponds and horizontal subsurface flow constructed 
wetlands treating domestic wastewater: a case study of the Juja sewage treatment works. J Environ Manage. 128:220-225.

Odinga CA, Swalaha FM, Otieno FAO, Ranjith KR, Bux F. 2013. Investigating the efficiency of constructed wetlands in the removal of heavy metals and enteric pathogens from wastewater. Environ Technol Rev. 2(1):1.

Paulo PL, Begosso L, Pansonato N, Shrestha RR, Boncz MA. 2009. Design and configuration criteria for wetland systems treating greywater. Water Sci Technol. 60(8):2001-2007.

Prochaska CA, Zouboulis AI, Eskridge KM. 2007. Performance of pilot-scale vertical-flow constructed wetlands, as affected by season, substrate, hydraulic load and frequency of application of simulated urban sewage. Ecol Eng. 31(1):57-66.

Ramprasad C, Philip L. 2016. Surfactants and personal care products removal in pilot scale horizontal and vertical flow constructed wetlands while treating greywater. Chem Eng J. 284:458-468.

Shah M, Hashmi H, N, Ali A, Ghumman A, R. 2014. Performance assessment of aquatic macrophytes for treatment of municipal wastewater. J Environ Health Sci Eng. 12(1):106. http://www.ijehse. com/content/12/1/106

Shelef O, Gross A, Rachmilevitch S. 2012. The use of Bassia indica for salt phytoremediation in constructed wetlands. Water Res. 46(13):3967-3976.

Shelef O, Gross A, Rachmilevitch S. 2013. Role of plants in a constructed wetland: current and new perspectives. Water. 5(2):405-419.

Srivastava J, Gupta A, Chandra H. 2008. Managing water quality with aquatic macrophytes. Rev Environ Sci Biotechnol. 7(3):255-266. DOI 10.1007/s11157-008-9135-x

Strong MT. 2006. Taxonomy and Distribution of Rhynchospora (Cyperaceae) in the Guianas, South America. Contrib. U.S. Natl. Herb. 65(1):87-102.
Taha SAH, Naqqiuddin MA, Omar H. 2015. Biology of Rhynchospora corymbosa in Outdoor conditions. Acta Biologica Malaysiana. 4(3):72-83.

Tuszyńska A, Obarska-Pempkowiak H. 2008. Dependence between quality and removal effectiveness of organic matter in hybrid constructed wetlands. Bioresour Technol. 99(14):6010-6016.

Vymazal J, Brix H, Cooper PF, Haberl R, Perfler R, Laber J. 1998. Removal mechanisms and types of constructed wetlands. Constructed wetlands for wastewater treatment in Europe. p. 17-66.

Vymazal J. 2011. Plants used in constructed wetlands with horizontal subsurface flow: a review. Hydrobiologia. 674(1):133-156.

Wu S, Wallace S, Brix H, Kuschk P, Kirui WK, Masi F, Dong R. 2015. Treatment of industrial effluents in constructed wetlands: challenges, operational strategies and overall performance. Environ Pollut. 201107-120.

Wurochekke AA, Harun NA, Mohamed RMSR, Kassim AHBM. 2014. Constructed wetland of Lepironia Articulata for household greywater treatment. APCBEE Procedia. 10:103-109.

Yang Q, Tam NF, Wong YS, Luan TG, Su WS, Lan CY, Shin PK, Cheung SG. 2008. The potential use of mangroves as a constructed wetland for municipal sewage treatment in Futian, Shenzhen, China. Mar Pollut Bull. 57(6-12):735-743.

Zhang DQ, Tan SK, Gersberg RM, Zhu J, Sadreddini S, Li Y. 2012 Nutrient removal in tropical subsurface flow constructed wetlands under batch and continuous flow conditions. J Environ Manage. 96(1):1-6.

Zhang D, Gersberg RM, Ng WJ, Tan SK. 2014. Removal of pharmaceuticals and personal care products in aquatic plant-based systems: a review. Environ Pollut. 184620.

Zurita F, White JR. 2014. Comparative study of three two-stage hybrid ecological wastewater treatment systems for producing high nutrient reclaimed water for irrigation reuse in developing countries. Water. 6(2):213-228. 